\title{
Hydrostatic Pressure Effects on Rabbit and Echinoderm Myosin ATPase
}

\author{
KARL F. GUTHE \\ Zoology Department, University of Michigan, Ann Arbor, Michigan'; and Bermuda Biological Station, \\ St. George's West
}

Received April 10, 1968; accepted March 26, 1969

\begin{abstract}
When saturated with ATP, sea cucumber myosin hydrolyzes ATP about 15 times more slowly than rabbit myosin, as expected from the slower contraction time of the muscle. The Arrhenius plots coincide at low temperatures, but only the rabbit plot changes slope at higher temperatures. This unexpected change in slope apparently results from the use of veronal buffer. At high substrate concentrations in veronal buffer, the enzymatic activities of the two proteins depend identically on ealoium ion and on $\mathrm{pH}$. The two myosins are equally inhibited by pressure at low $\mathrm{pH}$ and activated at high, suggesting that structural features common to the two enzymes are responsible for pressure sensitivity and its $\mathrm{pH}$ dependence.
\end{abstract}

An earlier paper (1) described the effects of temperature, $\mathrm{pH}$, and pressure on the ATPase activity of rabbit myosin. According to absolute reaction rate theory, these effects measure the changes that occur when the enzyme combines with reactants to form an active intermediate in the catalytic process. If some myosins differ from the rabbit enzyme in important structural features, they should show altered responses. Most likely to be different are myosins from phylogenetically distant organisms and the less active enzymes from slower muscles (2). As a slowly moving invertebrate to compare with the rabbit, the sea cucumber Stichopus moebii was chosen because it is abundant in Bermuda. The morphology of muscles of the related $S$. mollis (3) and $S$. juponicus (4) has been described.

Although this paper compares the responses of the two myosins, it also investigates the influence of the assay medium on the effect of moderate hydrostatic pressure

${ }^{1}$ Permanent address. This work was supported in part by a Rackham Summer Faculty Fellowship of The University of Michigan and by a grant (\#1611) from the Penrose Fund of the American Philosophical Society. (up to $500 \mathrm{~atm}$ ). The effect changes on substitution of veronal for Tris buffer or on addition of millimolar concentrations of calcium salts. This finding is shown to reconcile the varied reports of pressure effects on myosin ATPases found in the literature $(1,5,6)$. Although pressure also favors polymerization of myosin (7) and alters several properties of fresh and glycerinated muscle (reviewed by Brown (8)), it is premature to relate these effects to the enzymes.

\section{METHODS}

Myosins. After collection, the Stichopus were cooled for several hours to reduce the mucus secreted by handling. The thin layer of longitudinal and circular muscle, scraped from the inside of the thick connective tissue body wall, was ground in a mortar with extraction fluid and sand. During and after the grinding, the tissue stood in cold Guba-Straub extraction fluid $(3 \mathrm{ml} / \mathrm{g}$ tissue of KCl-phosphate, $\mathrm{pH} 6.2-6.3$, ionic strength 0.6 ) for about $30 \mathrm{~min}$. Centrifugation then removed debris, and myosin was precipitated by adding 20 vol of water to the supernate. The myosin precipitate was packed by centrifugation, redissolved in $0.6 \mathrm{M} \mathrm{KCl}$, and twice reprecipitated. It was stored in the cold as the precipitate. In the prepa- 
ration of rabbit myosin, a meat grinder was substituted for the mortar.

ATP. Four-hundred milligrams of ATP ( Na salt, Pabst) were dissolved in $0.07 \mathrm{M}$ recrystallized sodium veronal, and $0.07 \mathrm{~m}$ acetic acid was added to reach the desired $\mathrm{pH}$. This solution was then brought to $100 \mathrm{ml}$ by addition of $0.07 \mathrm{M}$ veronalacetate buffer of the desired $\mathrm{pH}$.

Activity. To $2 \mathrm{ml}$ of myosin suspension were added a small amount (usually $0.1 \mathrm{ml}$ ) of $0.1 \mathrm{M}$ $\mathrm{CaCl}_{2}$ and $2 \mathrm{ml}$ of ATP buffer. The $\mathrm{pH}$ of the mixture was that of the buffer. Hydrolysis of ATP was stopped after $30 \mathrm{~min}$ by addition of $4 \mathrm{ml}$ of $10 \%$ trichloracetic acid. Preliminary tests showed that hydrolysis was linear at the concentrations used for at least $40 \mathrm{~min}$, and dilution kept the activity low enough so that the enzyme was always saturated with substrate. Two milliliters of the TCAstopped mixture were used for determination of inorganic phosphate (Fiske-SubbaRow), which was corrected for the inorganic phosphate blank. Protein concentration was determined by microKjeldahl.

Pressure. The filled and stoppered test tubes were placed in pressure cylinders connected to a gauge and a hydraulic jack. Pressure was maintained at $6500 \mathrm{psi}(442 \mathrm{~atm})$ for $20 \mathrm{~min}$ of the 30 minute reaction time, and phosphate readings were corrected for $10 \mathrm{~min}$ hydrolysis at atmospheric pressure. Pressure was attained in about 15 sec and released in less than 1 sec.

\section{RESULTS}

In all experiments the ATP concentration was $3.1 \mathrm{~mm}$, so that the measurements apply to $V_{\max }$, the activity of the enzyme saturated with substrate, and not to the Michaelis constant. As expected, the myosin from the slower muscle showed less specific activity. At $\mathrm{pH} 8.0,25^{\circ}, 2.4 \mathrm{~mm} \mathrm{CaCl}_{2}$ and $3.1 \mathrm{~mm}$ ATP, in 0.07 M veronal-acetate buffer, a milligram of Stichopus myosin hydrolyzed $0.023 \mu$ mole of ATP per minute and rabbit myosin hydrolyzed 0.34 . To show that the rabbit myosin was not grossly contaminated with actin, a standard test for its ATP sensitivity (9) was performed. The myosin extract showed no change in viscosity on ATP addition, whereas authentic rabbit myosin B (natural actomyosin prepared by the usual 18- to 24-hr extraction with Weber-Edsall solution) showed the expected $100 \%$ sensitivity. The Stichopus myosin was not tested, but it responded like myosin to the various experi-

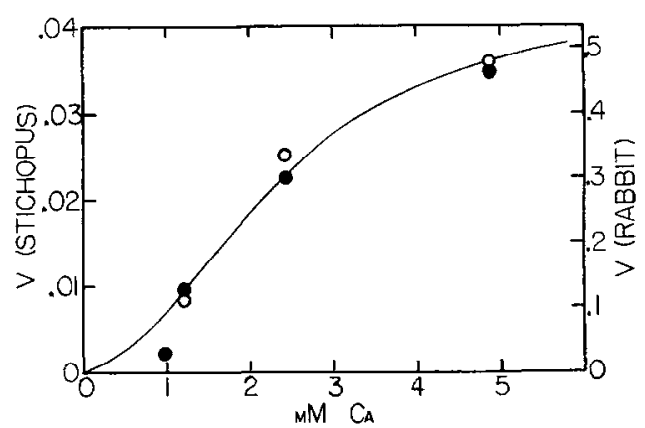

FIG. 1. Dependence of rabbit (O) and Stichopus myosin (O) ATPase activity on added $\mathrm{CaCl}_{2}$ at $25^{\circ}$. Ordinates: $V_{\max }$ in micromoles inorganic phosphate per milligram myosin per minute. 3.1 mм ATP, 0.07 m veronal-acetate, pH 8.0.

mental treatments described below, even though extracts from some other coldblooded animals behave like actomyosin (10) under other test conditions.

The calcium dependence of Stichopus and rabbit myosin ATPases was the same (Fig. 1). The calcium-activated hydrolysis by the Stichopus protein was completely inhibited by equimolar $\mathrm{MgCl}_{2}$, as expected for a myosin preparation that contains little actomyosin. Omission of both $\mathrm{Ca}^{2+}$ and $\mathrm{Mg}^{2+}$ reduced the Stichopus activity to undetectable levels (less than $2 \%$ of its activity with added calcium), the rabbit myosin to $2 \%$, and rabbit myosin $\mathrm{B}$ to $15-20 \%$. The Stichopus extract resembled myosin more than myosin B.

The two proteins responded differently to temperature. At $\mathrm{pH} 8$ and $2.4 \mathrm{~mm} \mathrm{CaCl}_{2}$, the apparent activation energy for Stichopus myosin was $19-22 \mathrm{kcal} / \mathrm{mole}\left(Q_{10} 3.4\right)$, or perhaps slightly less at the higher temperatures (Fig. 2). The apparent activation energy for rabbit myosin was $11-12 \mathrm{kcal} /$ mole $\left(Q_{10} 1.7\right)$ at high temperature but approached 19-22 at low, confirming our previous report. The difference between these results and the usual single slope of $12 \mathrm{kcal} / \mathrm{mole}$ for rabbit myosin is ascribed to the use of veronal as a buffer, as will be discussed below.

The two proteins respond to pressure indistinguishably. Activities were measured at $29^{\circ}$ in veronal at several $\mathrm{pH}$, at both atmospheric pressure and 442 atm (6500 psi) 
(Fig. 3). The activity ratio for the two enzymes varied with temperature, as seen in Fig. 2, and Figs. 1 and 3 were scaled for 29 and $25^{\circ}$, respectively. As the $\mathrm{pH}$ increased from 6.2 to 8.0 , the activities of the two myosins increased in the same way; both lacked the usual $\mathrm{pH} 6.4$ optimum when measured in veronal. Pressure slowed the hydrolysis at $\mathrm{pH} 6.8$, had little effect near $\mathrm{pH} 7$, and increased it at $\mathrm{pH} 8.0$ by comparable factors for the two myosins. This implies, according to absolute reaction rate theory, that hydrolysis is accompanied by a volume decrease at $\mathrm{pH} 8$ but a volume

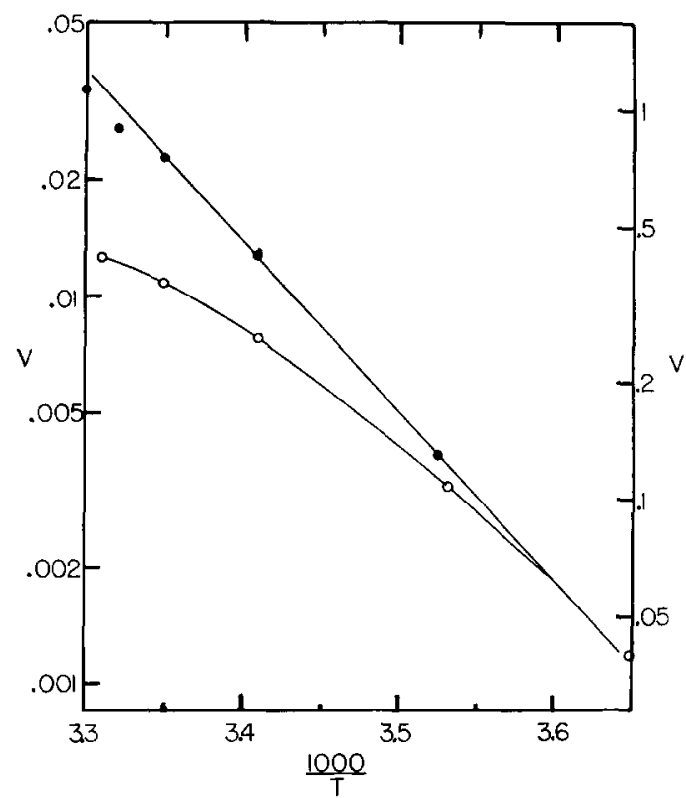

FIg. 2. Arrhenius plots for rabbit myosin ATPase (O, right ordinate) and Stichopus (O, left ordinate). $3.1 \mathrm{~mm} \mathrm{ATP,} 2.4 \mathrm{~mm} \mathrm{CaCl}_{2}, 0.07 \mathrm{M}$ veronal-acetate, $\mathrm{pH} 8.0$. increase below $\mathrm{pH}$ 7. The apparent volume changes are the same for the two myosins, implying structural similarity.

The present pressure results confirm our earlier report (1). Because other effects have been reported $(5,6)$, tests were performed using other assay media (Table I). If Tris or HEPES buffer was substituted for veronal, pressure activated myosin ATPase at $\mathrm{pH} 7$ to the same extent as reported in (5). Our earlier paper reported that pressure activation was independent of the concentrations of added calcium, provided it was in the millimolar range, but that omission of calcium decreased it. Others have reported (6) that pressure does not affect myosin A without added calcium, but the present preparation was too inactive without calcium to measure a pressure effect. Not adding calcium

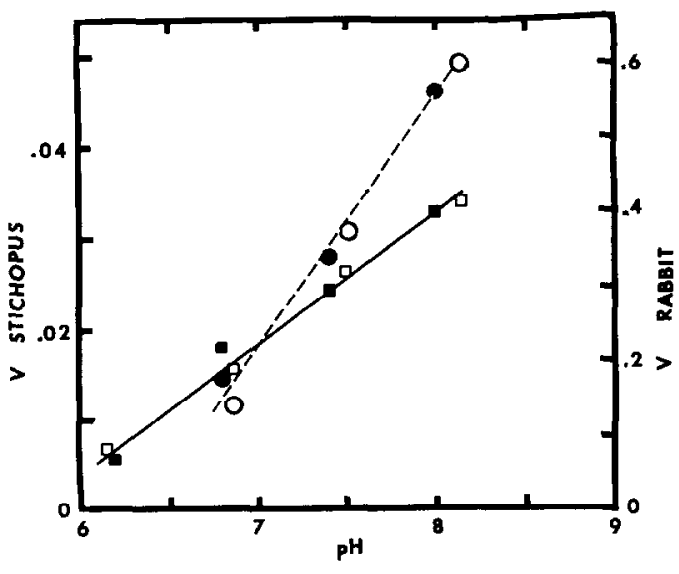

FIG. 3. Dependence of rabbit $(O, \square)$ and Stichopus $(0, \square)$ myosin ATPase on $\mathrm{pH}$ at atmospheric pressure (squares) 6500 psi (circles). $3.1 \mathrm{~mm}$ ATP, $2.44 \mathrm{~mm} \mathrm{CaCl}, 0.07$ m veronal-acetate, $29^{\circ}$.

TABLE I

Rabit ATPase at 550 Atmospheres in Percentage of Atmospheric Activity $\left(30^{\circ}, 5 \mathrm{~mm}\right.$ ATP, pH 7)

\begin{tabular}{lllll} 
Preparation & \multicolumn{1}{c}{ Buffer } & $\begin{array}{c}\text { Concentration of } \\
\text { added calcium }\end{array}$ & ATPase & Literature values \\
\hline Myosin A & 0.07 M Veronal-acetate & $4 \mathrm{mM}$ & $110 \%$ & $200 \%(5)$ \\
Myosin A & $0.10 \mathrm{M}$ Tris-maleate & 4 & 171 & 179 \\
Myosin A & $0.10 \mathrm{M}$ Na-HEPES & 4 & 97 & $57(6)$ \\
Myosin B & $0.05 \mathrm{M}$ Tris-Cl & 4 & 50 & 5 \\
Myosin B & $0.05 \mathrm{M}$ Tris-Cl & 0 & & \\
\hline
\end{tabular}


did modify the response of myosin B (Table I); pressure had little effect at $4 \mathrm{mu}$ calcium, but strongly inhibited myosin B ATPase in its absence, in agreement with (6).

\section{DISCUSSION}

The two enzymes obviously differ in maximal specific activity $\left(V_{\max }\right)$. As Bárány (2) has shown, ATPase rates generally parallel the rates of contraction of the source muscles. Rabbit myosin was prepared from a mixture of fast and slow muscles, and the effective contraction time should be intermediate. Contraction times for rabbit muscle are lacking, but in the cat at $36^{\circ}$ they are 27 msec for fast muscle and $75 \mathrm{msec}$ for slow (12). The $Q_{10}$ for cat muscle is 1.5 (13), so that corresponding times at $25^{\circ}$ are 40 and $112 \mathrm{msec}$. The contraction time for the sea cucumber $S$. regalis, in the same genus as $S$. moebii, is $1300 \mathrm{msec}(14)$, 12-33 times longer than the cat. At $25^{\circ}$ rabbit myosin hydrolyzes ATP 15 times faster than $S$. moebii myosin, in satisfactory agreement.

The two proteins also respond differently to temperature. At saturating ATP concentrations, the Arrhenius plot of $V_{\max }$ for Stichopus myosin is linear, with an apparent activation energy of $19-22 \mathrm{kcal} / \mathrm{mole}$. The rabbit myosin plot has the same slope as Stichopus only below $15-20^{\circ}$, and its apparent activation energy falls to 11-12 $\mathrm{kcal} /$ mole at higher temperatures. Calciumactivated rabbit myosin ATPase commonly shows a single constant slope corresponding to about $12 \mathrm{kcal} / \mathrm{mole}(2,11,15-18)$, as found here at high temperature. When modifiers like dinitrophenol, $p$-chloromercuribenzoate, or actin are present, however, it shows two slopes: $25 \mathrm{keal} / \mathrm{mole}$ below $16^{\circ}$ and $12 \mathrm{kcal} /$ mole above (11). We earlier interpreted our data as a reversible denaturation of the enzyme (1). With the modifiers, Levy et al. (11) and Azuma and Tonomura (16) argued for a temperature-dependent conformation change, as is also suggested for some other enzymes with biphasic Arrhenius plots (19-21). Possible schemes for the action of modifiers on myosin have been proposed $(16,18,22)$. The present results suggest that some modifier was present, and the only unusual feature was the use of veronal instead of Tris buffer. Apparently veronal acts on rabbit myosin like other modifiers. It is curious that Stichopus myosin remains in the low temperature form even at $30^{\circ}$, but the different responses of the two proteins show that temperature affects the rabbit myosin itself and not the medium.

Although different specific activities and temperature sensitivities suggest differences at the active site, $\mathrm{pH}$ and calcium ions affect the two proteins identically. The $\mathrm{H}^{+}$ and $\mathrm{Ca}^{2+}$ binding sites must be very similar. The $\mathrm{pH}$-dependent pressure effect on $V_{\max }$ is also the same for both myosins, and it reflects volume changes during the reaction, according to absolute reaction rate theory. Pressure inhibits at $\mathrm{pH} 6.8$ (corresponding to an apparent volume increase of $15 \mathrm{ml} /$ mole), has little effect at $\mathrm{pH} 7$, and activates at $\mathrm{pH} 8.0$ (a decrease of $20 \mathrm{ml} /$ mole). The size and sign of the pressure effect also depend on other experimental conditions. The negligible effect of pressure at $\mathrm{pH} 7$ in veronal becomes a sizable activation (a decrease of $25-33 \mathrm{ml} /$ mole as in (5)) if Tris or HEPES is substituted for veronal, suggesting again that veronal modifies myosin. Omission of calcium ions from the Tris medium is also significant, at least for myosin $\mathrm{B}$; with millimolar calcium pressure has little effect, but without it, as in the experiments of Rainford et al. (6), pressure inhibits the enzymatic activity. These workers also showed that it inhibits superprecipitation.

Pressure sensitivity, like a $Q_{10}$, only characterizes a reaction. It may reflect changes in hydration or ionization and not in conformation. However, a change from activation to inhibition by pressure, like a change in the slope of an Arrhenius plot, implies a significant change in the system. This might be a change in conformation or hydration at a flexible active site, or the charge near the active site might reverse with increasing $\mathrm{pH}$. Azuma and Tonomura (16) also suggest a $\mathrm{pH}$-dependent conformation change, based on their temperature-pH experiments. The pressure effects for the two enzymes are identical at all $\mathrm{pH}$ values studied. This implies that the active sites of the two enzymes 
resemble each other in hydration, charge, and flexibility.

The suggestion that veronal acts like other modifiers of myosin needs further experimental support. The identical effects of calcium ions, $\mathrm{pH}$, and pressure on the two ATPases emphasize the similarities among myosins, whereas the differences in specific activity and temperature sensitivity may be ascribed to the phylogenetic separation and different speeds of contraction of the source muscles.

\section{REFERENCES}

1. Brown, D. E. S., Guthe, K. F., Lawler, H. C., and Carpenter, M. P., J. Cell. Comp. Physiol. 52, 59 (1958).

2. Bárány, M., J. Gen. Physiol. 50, 197 (1967).

3. Freeman, W. P. and Simon, S. E., J. Cell. Comp. Physiol. 63, 25 (1964).

4. Kawaguti, S., AND Ikemoto, N., in "Molecular Biology of Muscular Contraction," p. 124. (Ebashi, S., Oosawa, F., Sekine, T., and Tonomura, Y., eds.), Igaku Shoin. Ltd., Tokyo, 1965.

5. Laidrer, K. J., and Beardeli, A. J., Arch. Biochem. Biophys. 55, 138 (1955).

6. Rainford, P., Noguchi, H., and Morales, M. F., Biochemistry 4, 1958 (1965).

7. Josephs, R., and Harrington, W. F., Proc. Natl. Acad. Sci. (U.S.) 68, 1587 (1967).
8. BRown, D. E.S. in "The Influence of Temperature on Biological Systems," p. 83. (F. H. Johnson, ed.), American Physiological Society, Washington, D. C., 1957.

9. Weber, H. H., and Poktzeinl, H., Advan. Protein Chem. 7, 161 (1952).

10. de Villafranca, G., and Hochgraf, H. L, Comp. Biochem. Physiol. 6, 147 (1962).

11. Levy, H. M., Sharon, N., Ryan, E. M., and Koshland, D. E., JR., Biochim. Biophys. Acta 56, 118 (1962).

12. Buller, A. J., Eccles, J. C.; And Eccles, R. M., J. Physiol. 150, 399 (1960).

13. Gordon, G., ANd Phillips, C. G., Quart. $J$. Exptl. Physiol. 38, 35 (1953).

14. Riesser, O., Arch. Expll. Pathol. Pharmakol. 172, 194 (1933).

15. Blum, J. J., Arch. Biochem. Biophys. 87, 104 (1960).

16. Azuma, N., and Tonomura, Y., Biochim. Biophys. Acta 73, 499 (1963).

17. Ouellet, L., Laidler, K. J., and Morales, M. F., Arch. Biochem. Biophys. 39, 37 (1952).

18. Sekine, T., and Kielley, W. W., Biochim. Biophys. Acta 81, 336 (1964).

19. Massey, V., Curti, B., and Ganther, H., J. Biol. Chem. 241, 2347 (1966).

20. Kayne, F. J., And Suelter, C. H., J. Am. Chem. Soc. 87, 897 (1965).

21. Kayne, F. J., And Suelter, C. H., Biochemistry 7, 1678 (1968).

22. Rainford, P., Hottta, K., and Morales, M. F., Biochemistry 3, 1213 (1964). 